\begin{tabular}{c|cc|c}
\hline 36 & $\begin{array}{c}\text { ARTIGLES } \\
\text { Jan DVOR̆ák }\end{array}$ & $\begin{array}{c}\text { Manifestations of Anti-Semitism in Gzechoslovak Silesia } \\
\text { during the First Republic [1918-1938] }\end{array}$ \\
\hline
\end{tabular}

\title{
Manifestations of Anti-Semitism in Czechoslovak Silesia during the First Republic (1918-1938) Jan DVOŘ́́K
}

\author{
Ústav pro studium totalitních režimů \\ The Institute for the Study of Totalitarian Regimes \\ Siwiecova 2, 13000 Praha, Czech Republic \\ jan.dvorak@ustrcr.cz
}

\section{Austrian Silesia at the turn of the $20^{\text {th }}$ century}

European society in the $19^{\text {th }}$ century was broadly secularized already, but all its classes were still strongly influenced by traditional Christian teaching, reflecting Christian (particularly Catholic) anti-Judaism. This attitude differed markedly from racial anti-Semitism, with its emphasis on the religious side of the problem and on non-violent manifestation. But from the $18^{\text {th }}$ century, it had already begun to transform, motivated mainly by competitively economic interests and finally leading to the national and ethnic anti-Semitism that later opened the floodgates to Nazi racism.

The growth of ethnic and social conflicts in multinational Austria-Hungary at the end of the $19^{\text {th }}$ century ${ }^{1}$ reflected negatively in the attitude of the population of Austrian Silesia towards local Jews. The atmosphere was also made tense due to a worsened economic situation, affecting lower social classes in particular. Workers' strikes and disorders, usually accompanied by the looting of Jewish shops, affected the regions of Ostrava and Opava at the end of the $19^{\text {th }}$ century. ${ }^{2}$

At that time, anti-Semitism also became a significant part of the propaganda of some political movements in these regions and it was particularly evident among Germans. From the 1880s, especially in the western part of Austrian Silesia (so-called Opavian Silesia), Jews were the target of the sharpest propaganda from the predecessors of German National Socialism - supporters of the anti-Semitic Schönerer ideology. ${ }^{3}$ In that respect, Opava

\footnotetext{
1 For more details, see e.g. FRANKL, Michal: "Emancipace od židů". Český antisemitismus na konci 19. století, Praha-Litomyšl 2007; DRÁBKOVÁ, Světlana: Vztah katolické církve a Židů v období aktivního antisemitismu vyvolaného nacismem, Dissertation thesis. Olomouc 2004. Department of church history of Cyril and Methodius Faculty of Theology of Palacký University in Olomouc, 6-12.

2 SPYRA, Janusz: Židé v rakouském Slezsku (1742-1918). Nástin dějin, in: Židé ve Slezsku. Studie k dějinám Židů ve Slezsku, SPYRA, Janusz - WODZIŃSKI, Marcin (eds.). Český Těšín, 2001, 43; TUREK, Alois: Předmájové dělnické bouře, 1. máj 1890 v Opavě, in: Sborník k 10. výročí osvobození města. Ostrava, 1956, 248-252.

3 The Schönerer movement was a nationalist movement of German turners at the turn of the $20^{\text {th }}$ century, characterized by the All-German and national anti-Semitic ideology of Georg Knight von Schönerer. Adolf Hitler was also inspired by the movement. For more details, see MÍŠKOVÁ, Alena: Od Schönerera ke genocidě?, in: Židé $v$ Sudetech/Die Juden im Sudetenland, OTTE, Anton (ed.), Praha, 2000, 48-49.
} 
ranked among prominent supporters of Schönerer and his followers. ${ }^{4}$ In subsequent years, however, most national movements abandoned the controversial Schönerer ideology, in order to obtain stronger electoral support. ${ }^{5}$

In addition to the nationalists, the German Silesian Popular Party existed at this time. This Christian-Socialist Party, which influenced the Slavic population, attacked Jews frequently as well, but it disassociated itself from racial anti-Semitism. ${ }^{6}$

In the early $20^{\text {th }}$ century, a new political entity - the German Workers' Party, characterized by strong anti-Semitism - started strengthening its influence, especially among German workers in the Czech frontier area who, until then, had supported social democracy. ${ }^{7}$

One finds a different situation from Opavian Silesia in Těšínian Silesia, where German liberals, resolutely rejecting anti-Semitism, had always had more influence among the German population. The propagation of racial anti-Semitism did not meet with a favourable response among the local public because many politically active Jews ranked among the leading industrial entrepreneurs. The religious orientation of the local population also played a role. The Protestants who had prevailed in the Těšín Region from the $17^{\text {th }}$ century were a little more tolerant towards Jews than the Catholics were. ${ }^{8}$

The anti-Jewish aversion of the Czechs (but also of the Polish), whose number was much higher in Těšínian Silesia than in Opavian Silesia, resulted primarily from strong interconnection of the Jews with German national consciousness and from their alleged involvement in the Germanization of the Czech (Polish) nation. However, such attitudes usually reflected social and economic motives in particular. The hatred against Jews could be seen not only in local conflicts but also in verbalized anti-Semitism during election battles in the nationally oriented Silesian press. In addition, leading Czech and Polish writers in the region attacked the Jews. In the Frýdek Region, and particularly in the Ostrava Region, strongly influenced by social democracy that advocated what was probably the most tolerant attitude towards Jews, there were no serious attacks against Jews at that time. ${ }^{9}$

From a social and national perspective, the situation in Austrian Silesia was radicalized again after the outbreak of World War I. In the violent actions of dissatisfied popular classes in the Ostrava and Těšín Regions, ${ }^{10}$ refugees from the Polish area of Galicia, including many orthodox Jews, faced the hatred of the local population. ${ }^{11}$

\footnotetext{
4 Schönerer and his co-workers led the Oppavia Association in Vienna. In the 1880s, the association developed a strongly nationalist orientation and a significant part of its program included racial anti-Semitism.

5 MÜLLER, Karel et al.: Dějiny českých měst. Opava, Praha 2006, 256.

6 SPYRA, 2001, 44-46.

7 GAWRECKI, Dan et al.: Dějiny Českého Slezska 1740-2000, part I., Opava 2003, 264; MíŠKOVÁ, 52.

8 SPYRA, Janusz: Ztracený svět Židů na Těšínském Sleszku / Utracony świat Żydów na Śląsku Cieszyńskim, Český Těšín 2013, 16

9 GAWRECKI et al., 2003, 250, 264; KLADIWA, Pavel - POKLUDOVÁ, Andrea - KAFKOVÁ, Renata: Lesk a bída obecních samospráv Moravy a Slezska 1850-1914. Muži z radnice, part II., vol. 1, Ostrava 2008, 418.

10 Provincial Archive of Opava (hereinafter referred only as "ZAO"), fund of Police Directorate of Moravská Ostrava (hereinafter referred only as "PŘMO"), sign. 1381, card file No. 180; Ibidem, sign. 1131, card file No. 188; Archive of the City of Ostrava (hereinafter referred to only as "AMO"), f. List of chronicles of villages and town quarters kept in the archive of the City of Ostrava, Chronicle of the Town of Hrušov. Annals of the Township of Hrušov, part I., pp. 161, 199, 202-203; Ibidem, Chronicle of the Town of Vítkovice 1914-1945, part II., 374-375, 377-378; GAWRECKI et al., 2003, 290-291.

11 E.g. Ostrava Region (hereinafter referred to only as "OK"), volume 13, 1918, issue 30, April 24
} 


\begin{tabular}{c|cr|c}
\hline 38 & $\begin{array}{c}\text { ARTIGLES } \\
\text { Jan DVOR̆ák }\end{array}$ & $\begin{array}{r}\text { Manifestations of Anti-Semitism in Gzechoslovak Silesia } \\
\text { during the First Republic [1918-1938] }\end{array}$ & \\
\hline
\end{tabular}

\section{National conflicts after World War I}

The disputes between the Czechs, the Polish and the Germans over the Silesian territory after the disintegration of Austria-Hungary and the revolutionary events of 1918 were reflected also in their attitude towards local Jews. The degree of hostility against Jews was directly related to the increasingly divisive Czechoslovak-Polish and Czechoslovak-German relations.

In the autumn of 1918, during the short six-week period of establishment of the Sudetenland province in Opavian Silesia, relations between the Germans and the Czechs became tense, but after the takeover of the territory by the Czechoslovak governmental authorities, the stormy nationalist tendencies gradually abated..$^{12}$ No openly anti-Semitic excesses occurred here.

The situation in Těšinian Silesia developed much more dramatically, from both a geo-political and a national perspective. During the dispute over the Těšín Region, further local nations - i.e. Silesians, Germans and Jews - came under the pressure of both the Czechs and the Polish, and they could thus potentially tilt the scales in the whole conflict. Therefore, both feuding parties forgot about their former antipathy towards the Jews and tried to win them over. But if any of the representatives of the Jewish minority actually supported one of the sides, getting praise and recognition, the other side responded with insults and disdain. Therefore, in the Czech and Polish press from the crisis years of 1918-1921 (including other than radically nationalist media), we can find a number of anti-Semitic attacks criticizing the Jews for their attitudes oriented against these or those national interests. ${ }^{13}$ But national motives often served as mere pretext for economic motives.

As compared to neighbouring regions, the Frýdek-Místek Region and the Ostrava Region experienced the most peaceful atmosphere from a national perspective. There were nationally motivated differences as well, reflecting markedly the surrounding national conflicts; but, due to the dominant number of Czechs, they had no chance of growing into a larger conflict. Notwithstanding, local Jews, constituting a considerable part of the local population, especially in Ostrava, could not feel completely safe after the end of World War I. The attacks against Jewish shops and businesses culminated during hunger demonstrations; the situation was constantly exacerbated by the high number of refugees from Galicia. ${ }^{14}$

12 ŽÁČEK, Rudolf: Slezsko. Stručná historie států, Praha 2005, 150.

13 E.g. Gwiazdka Cieszyńska (dále jen GC), vol. 72, 1919, issue 80, October 2; Opavský věstník, vol. 22, 1919, issue 82, October 21; GC, vol. 73, 1920, issue 118, May 29; GC, vol. 73, 1920, issue 47, February 27; Głos ludu ślaskiego, vol. 23, 1920, issue 34, May 8; Obrana Slezska, vol. 9, 1921, issue 40, October 1; Obrana Slezska, vol. 9, 1921, issue 38, September 17.

14 E.g. Ostravský kraj, vol. 13, 1918, issue 84, December 1; Ostravský deník, vol. 19, 1919, issue 177, August 5; Ostravský deník, vol. 20,1920, issue 86, April 16; GAWRECKI, Dan: Politické a národnostní poměry v Těšínském Slezsku 1918-1938, Studie o Těšínsku, vol. 15, Český Těšín 1999, 80- 81. 


\section{The 1920s: Anti-Semitism as a marginal social phenomenon}

The period of the First Republic has been perceived by many people as a time of predominantly idyllic coexistence of Jews with the rest of Czechoslovak society. The gradual mitigation of anti-Semitic moods was supported not only by the settled international situation, including consolidation of relations with neighbouring states (Germany, Hungary and Poland), but also by the gradual stabilization of the state economy in the early 1920s. The personality of President Masaryk must be also be credited; his authority contributed markedly to suppressing anti-Semitism, making it relatively quickly a marginal social phenomenon. ${ }^{15}$ Therefore, not only Czechoslovak Jews could feel safe in the new state, but also their fellow-believers from neighbouring countries where the approach to Jews was by far not nearly as tolerant as in Czechoslovakia.

Even so, it cannot be stated that antipathies towards Jews among the local population completely disappeared. The Czechs continued criticizing the Jews from a nationalist perspective as "Germanizers," disloyal to the Czech nation and newly to Czechoslovakia. Moreover, the stereotype of the Jew - as an unscrupulous greedy person - was deeply rooted in some social classes. German nationalists, active predominantly in the Czech frontier area, transformed their religious and national anti-Semitism into racial anti-Semitism. Nevertheless, the 1920s experienced attacks motivated by anti-Semitism only very sporadically - they included predominantly mild, most frequently verbal, manifestations. ${ }^{16}$ The Czechoslovak authorities succeeded, for the moment, in suppressing any serious conflicts before they escalated.

During the 1920s, national tendencies in Opavian Silesia did not differ much from the situation that had developed in other parts of the Czech-German frontier area. Both on the Czech and on the German side, anti-Semitism continued, hidden in national conflicts and skirmishes.

In addition to the movement of the German turners, the German National Party (DNP) expressed its negative attitude towards Jews, and in particular, the German National Socialist Worker's Party (DNSAP) bore a marked anti-Semitic character. ${ }^{17}$ Anti-Semitism was inherent in its program, in the form of a racially motivated defence. The strongest party organizations of Nazis were active only in some areas of Northern Moravia and Silesia. ${ }^{18}$

In the interwar period, anti-Semitism became apparent in a number of Nazi discussion

15 RATAJ, Jan: Český antisemitismus v proměnách let 1918-1945, in: Židé v české a polské občanské společnosti/Żydzi w polskim i czeskim społeczeństwie obywatelskim, VALENTA, Jaroslav - TOMASZEWSKI, Jerzy (eds.), Praha 1999, 48-49.

16 SOUKUPOVÁ, Blanka: Česká identita po vzniku Československé republiky. Antisemitismus jako faktor upevnění jsoucnosti? 1918-1920, in: Židovská menšina v Československu ve 20. letech, SOUKUPOVÁ, Blanka - ZAHRADNÍKOVÁ, Marie (eds.), Praha 2003, 37-38; SOUKUPOVÁ, Blanka: Český antisemitismus v podmínkách pluralistické demokratické společnosti národního státu, in: Židovská menšina v Československu ve 30. letech, POJAR, Miloš - SOUKUPOVÁ, Blanka - ZAHRADNíKOVÁ, Marie (eds.), Praha 2004, 21.

17 ZIMMERMANN, Volker: Sudetští Němci v nacistickém státě. Politika a nálada obyvatelstva v Řišské župě Sudety (1938-1945), Praha 2001, 328.

18 For more details see ŠEBEK, Jaroslav: Politické strany německé menšiny, in: Politické strany. Vývoj politických stran a hnutí v českých zemích a Československu 1861-2004, Období 1861-1938, part 1. MALíR, Jiř́ - MAREK, Pavel (eds.), Brno 2005, 869-871. 


\begin{tabular}{|c|c|c|}
\hline 40 & $\begin{array}{l}\text { ARTICIES } \\
\text { Jan DUOǨÁK }\end{array}$ & $\begin{array}{l}\text { Manifestations of Anti-Semitism in Gzechoslovak Silesia } \\
\text { during the First Republic [1918-1938] }\end{array}$ \\
\hline
\end{tabular}

evenings, lectures and articles in the party press. Such manifestations were quite close to the "big-mouthed" Schönererism of the $19^{\text {th }}$ century, and created fertile ground for ideas of National Socialism in the frontier area in the 1930s. ${ }^{19}$ At that time, a number of Nazi lectures, as well as attacks against Jews, took place in Opavian Silesia. Especially popular were the so-called "Sprechabends" - ideological lectures in which slogans against Jews and Communists were chanted, right hands were raised, nationalist songs were sung, etc. ${ }^{20}$ Rudolf Jung, the main speaker and party ideologist, was a frequent guest at such "evenings" and other similar events. ${ }^{21}$ Similar actions were not restricted only to the western part of Czech Silesia. Party speakers gave impassioned speeches also in the Těšín Region, accusing the Jews of contributing to the suffering and defeat of the German nation. ${ }^{22}$ The Nazi attacks against Jews culminated before elections, as evidenced, for example, by the campaign of DNSAP before the first ever post-war municipal election in Opava in 1920. ${ }^{23}$ The Nationalists were not as pronounced and decisive as the Nazis in their concept of anti-Semitism; ${ }^{24}$ nevertheless, DNP carried a strong anti-Semitic tone at times. The speakers often encouraged the audience to boycott Jewish and Czech shops. ${ }^{25}$

But the anti-Jewish campaign was implemented not only by German radicals. We can find anti-Semitic outbursts also in the printed materials of German Catholic parties; for example, Das Volk, the newspaper of the German Christian-Social Party, published in Krnov, not only branded Jews with anti-Semitic invectives typical for Christian anti-Judaism, ${ }^{26}$ but at the same time, accused them of supporting Communism. ${ }^{27}$

In the Těšín Region, particularly the local right-wing workers'press was promoter of anti-Semitism. The clerical press did not remain passive in this regard, in spite of the fact that the relation of the Těšínian Catholics to Jews was exemplary, as compared to the rest of the ČSR, and their anti-Semitism gradually abated. ${ }^{28}$

19 MíŠKOVÁ, 55.

20 GAWRECKI, 1999, 215; GAWRECKÁ, Marie: Němci ve Slezsku 1918-1938. Opava 2002, 53.

21 JUNG, Rudolf (16 April 1882, Plasy - 11 December 1945, Praha - Pankrác prison). Mechanical engineer. From 1909, DAP member; after 1918, DNSAP member. From 1920, deputy in National Assembly of ČSR; from 1926, president of DNSAP; in 1922, arrested and his party dissolved. In 1935, he left for Germany and taught, with the title of professor, at Political University. In 1936, he was admitted into the SS, finally getting the SS-Obergruppenführer rank. After returning to the Protectorate, his political work was prevented by K.H. Frank. In December 1944, he was charged with the area of appointment orders. He was arrested in May 1945 and he died in Pankrác prison.

22 ZAO, f. PřMO, sign. 1099, card file No. 200; GAWRECKI, 1999, 215.

23 GAWRECKÁ, 74.

24 The program principles of DNP were based, similarly to DNSAP principles, on the Great German national consciousness and the negative German attitude towards the foundation of the Czechoslovak Republic. But the program included evident traits of anti-Semitism as well. See ŠEBEK, 873.

25 GAWRECKÁ, 85.

26 E.g. Das Volk, vol. 1, 1919, issue 235, September 26.

27 Das Volk, vol. 1, 1919, issue 182, July 24.

28 It was facilitated by the fact that, after the Těšín Region had been divided, the Catholic Church in its Czechoslovak part remained at the periphery of interest for the Wroclaw and the Czech or Moravian and Polish bishops, and therefore different aggressive ideologies, including anti-Semitism, arrived there with a delay, and therefore, with less intensity. The willingness to tolerate other religions or religious groups was supported also by the experience of long years of coexistence by the Catholics with numerous and socially influential Protestants. SZYMECZEK, Józef: Židé na Těšínsku, 2, [online] available at: 
In addition to the Jew (usually a wholesaler or successful entrepreneur) who goes against national interests, the pages of some Czech and Polish regional newspapers continued publishing articles that condemned Jews with the help of the stereotypes of that time: Jew - usurer, Jew - cheater, Jew - agitator against social order, etc. Other Jews were attacked for their sympathies with left-wing movements. ${ }^{29}$ All the above-stated stereotypes were often conflated.

Hunger demonstrations that grew into the plundering of Jewish property occurred even after the war in the Těšn Region. One of the most radical protests that allegedly endangered some Jews' lives took place on Maundy Thursday of 1919 in Bohumín-Station. During the workers' meeting in the square in front of the church, aimed at forcing reduced prices from shopkeepers, some people even built gallows for Jewish shopkeepers. ${ }^{30}$ Other openly anti-Semitic manifestations took place in the Těśn Region in subsequent years, but only exceptionally - and when they did, they occurred mainly on the Polish side of Těšín. ${ }^{31}$

In the Czech environment, hatred against Jews remained linked mainly to aversion against Germanizers - industrial leaders controlling the region - and against the large and successful group of Jewish sole traders from different areas. In the Ostrava Region in particular, Jews constituted significant, almost unbeatable economic competition. The economic motives underlying anti-Semitism were masked again behind morally more acceptable national or religious interests. ${ }^{32}$ In the first years after foundation of the ČSR, many newspapers kept alluding to the refugee problem. ${ }^{33}$ The Ostrava Region was, of course, immediately affected also by the Czechoslovak-Polish dispute over the nearby Těšín Region, in which the authorities of both states expelled members of the other nationality from their territories, leading to a growing influx of refugees. ${ }^{34}$

Any Silesian Jews trying to assimilate into the Czech nation were always considered "turncoats" by Czech nationalists. Accusations of their exaggerated embrace of the German national consciousness, their insufficient national sentiment and their hypocrisy dominated the Czech press (especially the nationalist press) essentially throughout the interwar period. ${ }^{35}$ For example, one article in the Obrana Slezska newspaper creates an almost comical impression when it compares the "colonization" of the Beskydy Mountains (which, actually, consisted primarily of business activities) to the colonization of the Holy Land. ${ }^{36}$ But some articles overstepped the tolerable limit and became the subject of police investigations try-

http://www.go-east-mission.net/dateien/cz/146_260209.pdf [cit. 24-11-2014]

29 E.g. GC, vol. 72, 1919, issue 61, August 8; Ibidem, vol. 72, 1919, issue 66, August 26; Ibidem, vol. 73, 1920, issue 9, January 13; Ibidem, vol. 73, 1920, issue 37, February 15; Ibidem, vol. 73, 1920, issue 64, March 18; Ibidem, vol. 73, 1920, issue 142, June 27.

30 GC, vol. 72, 1919, issue 44, June 10.

31 SPYRA, Janusz: Po stopách těšínských Židů: malý průvodce po židovských památkách v Cieszyně a Českém Těšíně, Cieszyn 2004, 7.

32 E.g. Ostrava Region (hereinafter referred to only as "OK"), volume 13, 1918, issue 87, December 21.

33 OK, vol. 14, 1919, issue 18, February 26.

34 AMO, f. District Council of Moravská Ostrava (hereinafter referred to only as "OÚ MO"), inv. No. 872, card file No. 10.

35 E.g. Obrana Slezska, vol. 15, 1927, issue 9, February 25; Ibidem, vol. 13, 1925, issue 28, July 10.

36 Ibidem, volume 15, 1927, issue 49, December 2. 


\begin{tabular}{|c|c|c|}
\hline 42 & $\begin{array}{l}\text { ARTICLES } \\
\text { Jan DUOŘÁK }\end{array}$ & $\begin{array}{l}\text { Manifestations of Anti-Semitism in Gzechoslovak Silesia } \\
\text { during the First Republic [1918-1938] }\end{array}$ \\
\hline
\end{tabular}

ing to fight consistently against anti-Semitic manifestations in the press. ${ }^{37}$ And the attacks against Jews did not find positive response in society either. ${ }^{38}$

However, it is important to note that during the 1920s, fascist groups started emerging on the domestic political scene, making use of social demagoguery for their political advancement. And the regions of Northern Moravia and Silesia offered the strongest support for the fascists. For example, the important positions of Jews in many (especially left-wing) political parties were a thorn in their side. ${ }^{39}$ But cases of physical attacks or the torture of Jewish fellow citizens remained rare in the 1920s.

\section{Increasing anti-Semitic moods in the 1930s}

In the early 1930s, the character of anti-Semitism in Czechoslovakia started gradually changing, for both international and internal reasons. The most important of them was the situation in neighbouring Germany, where the Nazis had assumed power in 1933. Anti-Semitism played a clear role in the Nazi political program; after two years, it was even codified in the Nuremberg Laws passed by the Reichstag in September 1935.

The development of events in Germany in the early 1930s contributed to the increasing ideological and political activity of German negativistic parties ${ }^{40}$ in Czechoslovakia, namely DNSAP and DNP. The Nazis in particular no longer suppressed their anti-Semitism. Soon after both parties were banned in 1933, another political entity emerged on the political scene - the Sudeten German Patriotic Front (later renamed to the Sudeten German Party - SdP). The Henleinists, supported by more and more Germans from the Czech frontier area, searched for inspiration in Germany, even for a solution to the "Jewish issue." That resulted in more and more frequent boycotts against Jewish shops, businesses or experts by Sudeten Germans, as well as other anti-Semitic excesses in the frontier area. ${ }^{41}$ In 1937, and especially in the critical year 1938, anti-Semitic acts of violence increased in number, culminating before the signing of the Munich Agreement in September 1938.42

But it was not only the German population of the frontier area that flirted more and more frequently with anti-Semitic ideas. Anti-Semitism, which had adapted to the new situation after a decline in the 1920s, acquired more and more supporters also in Czech society. Its propagators were able to profit primarily from social and economic problems, as well as from the deficient operation of the mechanism of the Czechoslovak parliamentary

37 E.g. AMO, f. OÚ MO, inv. No. 123, card file 18.; Ibidem, inv. No. 1502, 1507, card file 6.

38 One of the typical manifestations of anti-Semitism in the town of Orlová was described by Peter Beck; for more details, see BECK, Petr: Samuel Scharf, židovský hasič z Orlové a český antisemitismus, in: Židé ve Slezsku. Studie k dějinám Židů ve Slezsku, SPYRA, Janusz - WODZIŃSKI, Marcin (eds.), Český Těšín 2001, 104-111.

39 GAWRECKÁ, 118.

40 The negativistic parties did not cooperate with Czechoslovak parties; during their entire existence, they advocated the extinction of the republic.

41 ČERMÁKOVÁ, Radka: Československá pluralistická demokratická společnost ve stínu nacistického Německa, in: Židovská menšina v Československu ve 30. letech, POJAR, Miloš - SOUKUPOVÁ, Blanka - ZAHRADNÍKOVÁ, Marie (eds.), Praha 2004, 14; KOCOUREK, Ludomír: Okupované pohraničí a holocaust, in: Historie okupovaného pohraničí 12, RADVANOVSKÝ, Zdeněk (ed.), Ústí nad Labem, 2006, 93.

42 KREJČOVÁ, Helena: Židovská komunita v Sudetech a její osudy po Mnichovu, in: Židé v Sudetech/Die Juden im Sudetenland, OTTE, Anton (ed.), Praha 2000, 131-132; ZIMMERMANN, 328. 
democracy. In the 1930s, anti-Semitism become more prevalent in some political parties (Czechoslovak National Democracy, Agrarian Party, National League) and in particular in a number of fascist ${ }^{43}$ and nationalist organizations (National Fascist Community, Flag, National Union), which influenced the lower social classes primarily with the help of social demagoguery. ${ }^{44}$ With growing radicalism in Czech society, not only Jewish expatriates and immigrants, arriving in larger and larger numbers to its territory, and German Jews, but also Czechs of Jewish origin were declared undesirable and parasitic foreigners. ${ }^{45}$

The impact of the Great Depression that affected the entire world in the early 1930s was felt among the population of the predominantly industrial Silesia. High unemployment affected the German, Polish and Czechoslovak parts of Silesia and exasperation grew, especially among workers. Many strikes and hunger demonstrations took place all over Silesia; some of them were brutally suppressed by state power. ${ }^{46}$ Sharpened national conflicts resulted in growing anti-Semitic antipathy once again. ${ }^{47}$ The whole situation was worsened by the influx of predominantly Jewish refugees from Germany and later from Austria. The territory of Czech Silesia and the Ostrava Region with its advanced industry ranked among the parts of Czechoslovakia where refugees most frequently landed. In contrast to top state officials and assistance organizations, who were welcoming to the Jewish refugees, the general public exhibited an increasingly negative response.

Similar to the situation in other Czech frontier areas with large German populations, Opavian Silesia saw more and more manifestations of hostility towards Jews in the 1930s. ${ }^{48}$ The Nazis made frequent use of the press to propagate their hateful opinions. In early 1933, the Bildungsamt der DNSAP (Educational Office of DNSAP) was founded in Opava under personal leadership of R. Jung. The Educational Office for the Opava and Ostrava Regions issued, among other promotional materials, texts with anti-Semitic and anti-communist content like photo captions for lectures. Other articles published in the party press or discussions organized by the Nazis had similar content. ${ }^{49}$

From time to time, other regional German and Czech newspapers also published texts in which the authors did not hesitate to attack Jews, and some authors compared favourably with their Nazi colleagues. At times, such articles even became the subject of police investigation. For example, an unknown author attacked alleged Polish Jews in his article published in Krnovské noviny and asked for their eviction..$^{50}$ Nevertheless, the complaints of some Jews about the openly hateful article had no effect and the author was not sanc-

43 Czech fascists found protection and examples of anti-Semitic measures also in Polish nationalist parties (Stronictwo Narodowe, Narodowo-Społeczna Partia Radykalna, atd), with which they developed intensive contacts.

44 For more details see e.g. PAVLÍČEK, Jaromír: Český fašismus, in: Politické strany. Vývoj politických stran a hnutí v českých zemích a Československu 1861-2004, Období 1861-1938, part 1, MALíř́, Jiří - MAREK, Pavel (eds.), Brno 2005, 637-644.

45 RATAJ, 54-55.

46 ŽÁČEK, 159.

47 WANATOWICZ, Maria W.: Historia społeczno-polityczna Górnego Śląska a Śląska Cieszyńskiego w latach 1918-1945, Katowice 1994, 116.

48 PLAČEK, Vilém: Prajzáci aneb k osudům Hlučínska 1742-1960, Hlučín 2000, 71.

49 CÉSAR, Josef - ČERNÝ, Bohumil: Politika německých buržoazních stran v Československu v letech 19181938, part II, Praha 1962, 136, 172; GAWRECKÁ, 164, 167-168.

50 Krnovské noviny, vol. IV (XIII), 1935, issue 21, October 2. 


\begin{tabular}{|c|c|c|}
\hline 44 & $\begin{array}{l}\text { ARTIGLES } \\
\text { Jan DUOŘÁKK }\end{array}$ & $\begin{array}{l}\text { Manifestations of Anti-Semitism in Gzechoslovak Silesia } \\
\text { during the First Republic [1918-1938] }\end{array}$ \\
\hline
\end{tabular}

tioned in any way. ${ }^{51}$

The 1930s witnessed not only verbal attacks or invectives in the press but also the first dangerous threats that could possibly lead to tragedy. The police reports tell us that on 10 October 1933, an attack against the Opava synagogue was being prepared for when the "Hanigun" choir from the German Reich was to give a concert there. But for the time being, nothing more than threats occurred. ${ }^{52}$ On the contrary, several years later, local society was shocked by the racially motivated murder of Walter Rosenzweig, head of the Sigmund Perutz factory, committed on 26 November 1935 by Karl Scheithauer, an SdP activist from Bruntál. ${ }^{53}$

More numerous open manifestations of Jewish persecution occurred in Opavian Silesia in 1938. The centres of anti-Semitic riots in the Czech frontier area included Opava or Frývaldov, important centres for the Henleinists. ${ }^{54}$

In premonition of imminent disaster, many local Jews preferred to leave their homes voluntarily. Their number started decreasing after the Austrian "Anschluss" of March 1938. The first major wave of people on the run from the frontier area of the republic surged after the mobilization was announced in May 1938.

Jews in the Czech frontier area started experiencing direct attacks after the well-known speech given by Hitler in Nuremberg on 12 September 1938, in which he threatened military invasion into the ČSR. The towns of Opavian Silesia witnessed the loud anti-Czechoslovak rage of self-confident Henleinists. In addition to excesses against Czechs and Czechoslovak authorities, attacks against Jews grew in number too. At that time, the second and even larger wave of people fleeing from the frontier area surged. ${ }^{55}$

In Těśnian Silesia, the national situation was partially stabilized by the late 1920s. The weakened positions of radical nationalists were reflected also in the intensity of their campaigning, including the frequency of anti-Semitic attacks. In spite of that fact, the picture of the Jew as an unscrupulous Germanizer who oppresses and impoverishes the Czech or Polish population can be considered "deep-rooted folklore" in their presentation. From Jablunkov to Frýdek, Jews were labelled as a pro-German element by Czech nationalists. ${ }^{56}$ Nationalistically oriented periodicals even presented the absurd accusation that local Jews were the strongest supporters of Nazism. ${ }^{57}$

Although in the eastern part of Czech Silesia, the German minority was much smaller than in the west, local Germans sympathized more and more with Nazi ideology. Slogans against Jews, Communists, etc. could be heard at Nazi meetings and "Sprechabends" in

51 ZAO, f. PŘMO - national police records 1/2, sign 2650, card file 389.

52 ZAO, f. PŘMO - national police records 1/2, sign. 3059, card file 355 a.

53 STEJSKAL, Jan - TESǍ̆, Petr - KUČA, Pavel: Otisky poutníka Ahasvera. Z historie židovské obce v oblasti Krnova, Bruntálu, Budišova nad Budišovskou a Osoblažska, Moravský Beroun 2002, 32. After Bruntál had been occupied by the German army, Scheithauer returned there. Shortly before the town was liberated by the Russian army in 1945, he escaped and his crime probably went unpunished.

54 MíŠKOVÁ, 56.

55 KREJČOVÁ, 136; KURAL, Václav - RADVANOVSKÝ, Zdeněk: „Sudety“ pod hákovým kř̌ržem, Ústí nad Labem 2002, 54.

56 Obrana Slezska, vol. 19, 1931, issue 43, October 23.

57 Frýdecko-Místecký kraj, vol. 11, 1934, issue 26, June 30; Frýdecko-Místecký kraj, vol. 11, 1934, issue 31, September 1. 
the Ostrava and Frýdek Regions. ${ }^{58}$ Some Nazis did not hesitate to insult Jews verbally in public; ;9 offensive inscriptions could be seen on Jewish shops. ${ }^{60}$ In spite of such recorded incidents, the Jews in the Czechoslovak part of the Těšín Region lived for the most part in symbiosis with their surroundings, as compared to their Polish fellow-believers. ${ }^{61}$ Not only the German, but also the Polish part of Upper Silesia was hit by a strong wave of anti-Semitism in the 1930s. The Polish nationalists and radical Catholics initiated a number of anti-Semitic actions and provocations in Těšín and in other towns of Těšínian Silesia. ${ }^{62}$ Further, the influence of radical Polish parties spread to the Czechoslovak Těšín Region. The Polish government, wishing to change the border and to annex so-called Zaolží (Zaolzie) to Poland, intentionally stirred up anti-Semitism by propagating ideological content among the local Poles. Over the course of the dramatic year of 1938, the propaganda of Polish nationalist circles striving to annex the Těšín Region grew harsher. Periodicals with anti-Czech and anti-Semitic content spread throughout the Těšín Region. ${ }^{63}$

Although Czech and Polish nationalists represented different national interests, the mutual inspiration of those radical movements is apparent - it manifested primarily in the continuing refusal of the German and Jewish elements in society. But unlike their Polish colleagues, Czech radicals concentrated "only" on preservation of anti-Semitic moods among the Czechs, last but not least in view of the threat of hard sanctions from state authorities. ${ }^{64}$ In particular, Czech fascists strived to extend their electoral base in the Těšín Region, as they did not have as firm a position as the fascists in the neighbouring Ostrava Region. In the tense atmosphere of the first half of 1938, the fascists from the National Fascist Party (NOF), in spite of railing against Marxism, did not hesitate to hold talks with the Communists, finding even an ally among them - Karol Śłiwka, a Communist senator and wellknown anti-Semite. ${ }^{65}$ From May 1938, the SdP also intensified its campaigning in the Těšín Region; at that time, its anti-Semitism could not be doubted at all. Local Germans acted there together with the Šlonzákovci Party, and that pro-German bloc became the strongest election coalition in several local towns. ${ }^{66}$

In the days just before the events in Munich, when the Polish intensified their demands on cession of the Těšín Region, the Těšín and Ostrava Regions witnessed attacks against Czech and Jewish properties committed by Polish commandos. ${ }^{67}$ The Těśn Region even has one sad claim to notoriety, as the first bomb attack against a Jewish building in Czecho-

58 GAWRECKÁ, 167.

59 ZAO, f. PŘMO, sign. 13/224, card file No. 350 a.

60 ZAO, f. PřMO, sign. 2724, card file No. 389.

61 TOMASZEWSKI, Jerzy: Zarys dziejów Żydów w Polsce w latach 1918-1939, Warszawa 1990, 58.

62 SPYRA, 2004, 7; KRÓL, Jan, Żydzi na Śląsku Cieszyńskim, in: Kalendarz Cieszyński, vol. 6, 1990, 65; JAWORSKI, Wojciech: Żydzi w Cieszynie w okresie międziwojennym, in: Pamiętnik cieszyński, vol. 6, 1993, 101-102; PASZ, Franciszek: Żydzi i My w Cieszynie, Cieszyn 1995, 63-65.

63 GAWRECKI, 1999, 356.

64 Ibidem, 346.

65 GREGOROVIČ, Miroslav: Kapitoly o českém fašismu. Fašismus jako měřítko politické dezorientace. Legenda a skutečnost, Praha 1995, 82.

66 GAWRECKÁ, 85.

67 GAWRECKI, 1999, 367. 


\begin{tabular}{r|cr|}
\hline 46 & $\begin{array}{c}\text { ARTICLES } \\
\text { Jan DVOR̆ÁK }\end{array}$ & $\begin{array}{c}\text { Manifestations of Anti-Semitism in Gzechoslovak Silesia } \\
\text { during the First Republic [1918-1938] }\end{array}$ \\
\hline
\end{tabular}

slovakia of that period took place there. In late September 1938, i.e. more than one month before so-called Crystal Night, members of a Polish commando blew up a part of the office buildings of the Trinec synagogue. ${ }^{68}$ Fear of further anti-Semitic excesses weighed heavy on the local Jewish community in those days. Therefore, the Jews started fleeing from there as well.

In the predominantly industrial Ostrava Region, where the impacts of the economic crisis of the 1930s were considerable, the Czech fascists - particularly NOF - kept strengthening their positions. Their campaigning focused in particular on local workers and the middle class, but gradually, the fascists concentrated also on other groups - e.g. local smallholders. ${ }^{69}$ To assert their ideological opinions, they used primarily leaflets, ${ }^{70}$ the party press ${ }^{71}$ and appearances at public meetings. ${ }^{72}$ Slogans asking for the "elimination" of Jews and "cleansing" towns of Jews, a ban on authorizing Jews and emigrants to operate shops and businesses, etc. became popular in their presentation. ${ }^{73}$ Economic and national fears were directed more and more frequently not only towards the massive numbers of Jewish immigrants but also against local Jewish ethnic groups. ${ }^{74}$ Any efforts by the Ostravian Jews to assimilate into the Czech nation were considered only false manifestations of Czech national consciousness. ${ }^{75}$ The adverse consequences of Jewish immigration to the region - lack of housing, competition to stallholders and shopkeepers - became the dominant topic for fascists and other demagogues in 1938. ${ }^{76}$ Their strong influence in the Ostrava Region is evidenced also by the fact that a state-wide congress was to be held there at the turn of October 1938, to solve the Jewish issue, among other things. But after the events in Munich, the congress did not take place. ${ }^{77}$

In the crisis year of 1938, Jew-intolerant phenomena could be seen not only in radical movements but more and more frequently also in some forces that had been democratic up until then. Their frequency increased proportionally to the growing feeling of danger about the Czechoslovak state. They included primarily reproaches against Jews with regard

68 BORÁK, Mečislav: Situace židovského obyvatelstva na území českého Slezska v době okupace (1938-1945), in: Židé ve Slezsku. Studie k dějinám Židů ve Slezsku, SPYRA, Janusz - WODZIŃSKI, Marcin (eds.), Český Těšín 2001, 148.

69 GREGOROVIČ, 75

70 E.g. ZAO, f. PǨMO, sign. 6/368, card file No. 393.

71 In the interwar period, three fascist periodicals were published in Moravská Ostrava by NOF or by its top representatives - Obrana národa, Moravskoslezský fašista (or Moravský fašista, respectively) and Národní směr. HABRMANOVÁ, Magda: Český fašistický tisk na Ostravsku, in: Slezský sborník, 91, 1993, 1/2, 44.

72 GAWRECKI, $1999,347$.

73 For more details on the activities of Czech fascists and particularly those of the NOF in the 1930s, see e.g. PASÁK, Tomáš, Český fašismus 1922-1945 a kolaborace 1939-1945, Praha 1999, 109-155.

74 E.g. Národní směr (dále jen NS), vol. 1, 1937, issue 15, October 23; NS, vol. 1, 1937, issue 5, July 16; NS, vol. 1, 1937, issue 1, June 11; NS, vol. 1, 1937, issue 8, September 24; Moravský fašista (hereinafter referred to only as "MF"), vol. 3, 1937, issue 15, May 7.

75 E.g. MF, vol. 3, 1937, issue 3, January 22; MF, vol. 3, 1937, issue 12, April 9; NS, vol. 1, 1937, issue 7, September 3; NS, vol. 1, 1937, issue 20, October 9; NS, vol. 2, 1938, issue 21, August 26.

76 GRACOVÁ, Blažena: Židovské obyvatelstvo Ostravska v období druhé republiky, in: Sborník prací Filozofické fakulty Ostravské univerzity - Historie/Historica, 153, 1995, 3, 75; HABRMANOVÁ, Magda: Národní obec fašistická, in: Časopis Slezského muzea: série B - vědy historické, 42, 1993, 3, 225.

77 HABRMANOVÁ, Národní obec fašistická, 227. 
to their language orientation - use of German language in common life. ${ }^{78}$ But demagogic declarations created a diversion from burning issues in the economic and social spheres of everyday life.

Over the course of 1938, more serious attacks occurred also in the Ostrava Region. At that time, the Ostrava police had to deal with a number of cases of threats and even physical attacks by Czech fascists or supporters of SdP and NSDAP. ${ }^{79}$ Primarily wealthier Jews, in premonition of a bad future, sold their properties, withdrew money from their accounts and prepared for emigration. Those who underestimated the situation usually paid dearly for their belief later.

After the Munich Agreement was signed, there was a final turn and any remaining calmness disappeared for all Czechoslovak Jews. Although the situation from 1938 to 1945 differed in many aspects in different parts of Czech Silesia, including the approach of the occupation authorities towards the Jews, the line of the occupation policy concerning the "solution of the Jewish issue" was characterized by the development from initial deprivation of rights to expropriation and deportation to mass murder.

\section{Abstract}

The study discusses the manifestations of anti-Semitism on the territory of Czech Silesia during the period of the so-called First Republic (1918-1938). It charts its evolution and outlines the motives that led to the development of anti-Semitic moods. In spite of predominantly minor incidents and anti-Semitic manifestations resulting most frequently from the worsened economic situation of the non-Jewish population or from national problems omnipresent in multinational Czechoslovak Silesia, local Jews were respected by the majority society during a considerable part of the interwar period. The majority society was aware of their importance. But in the second half of the 1930s, life conditions started worsening for local Jews. Proportional to the escalating demands of Nazi Germany on cession of the Czech frontier area, anti-Semitism provoked by Nazi propaganda grew stronger. In Opavian Silesia in particular, where the German population prevailed, anti-Semitic disturbances by Nazi sympathizers grew in number. The Jews in the Těšn and Ostrava Regions could not feel completely safe at that time either. Czech and Polish radicals were not immune to accusing Jews of embracing German national consciousness, even though they were being persecuted by the Nazis. The hatred against Jews was intensified also by the influx of Jewish refugees from the Reich and later from Austria, in search of rescue from Nazi persecution. After the Munich Agreement was signed in late September 1938, there was a final turn and any remaining calmness disappeared for all Czechoslovak Jews.

78 E.g. Polední deník (hereinafter referred to only as "PD"), 1938, issue 83, April 9; České Slovo (hereinafter referred to only as "ČS"), vol. 10, 1938, issue 107, April 17; PD, vol. 39, 1938, issue 181, August 8; Ostravský kraj (hereinafter referred to only as "OK"), vol. 33, 1938, issue 41, May 28; Moravskoslezský deník, vol. 39, 1938, issue 177, June 29; ČS, vol. 10, 1938, issue 145, May 26; OK, vol. 33, 1938, issue 35, May 7; OK, vol. 33, 1938, issue 52 , July 13.

79 E.g. AMO, f. OS MO, inv. no. 1479; Ibidem, inv. no. 1487. 


\begin{tabular}{c|cr|c}
\hline 48 & $\begin{array}{c}\text { ARTIGLES } \\
\text { Jan DVOǨák }\end{array}$ & $\begin{array}{c}\text { Manifestations of Anti-Semitism in Gechoslovak Silesia } \\
\text { during the First Republic [1918-1938] }\end{array}$ & \\
\hline
\end{tabular}

\section{Keywords}

Jews, anti-Semitism, refugees, Czechoslovak Silesia, Ostrava Region, First Republic

\section{References}

Archive of the town of Ostrava (AMO)

Fund of chronicles of towns and town quarters kept in the Archive of the town of Ostrava Fund of the District Authority of Moravská Ostrava (OÚ MO)

Provincial Archive of Opava (ZAO),

Fund of Police Directorate of Moravská Ostrava (PǨMO)

České Slovo, vol. 10, 1938.

Das Volk, vol. 1, 1919.

Frýdecko-Místecký kraj, vol. 11, 1934.

Głos ludu ślaskiego, vol. 23, 1920.

Gwiazdka Cieszyńska, vol. 72, 1919; vol. 73, 1920.

Krnovské noviny, vol. IV (XIII), 1935.

Moravskoslezský deník, vol. 39, 1938.

Moravský fašista, vol. 3, 1937.

Národní směr, vol. 1, 1937; vol. 2, 1938.

Obrana Slezska, vol. 9, 1921; vol. 13, 1925; vol. 15, 1927; vol. 15, 1927; vol. 19, 1931.

Opavský věstník, vol. 22, 1919.

Ostravský deník, vol. 19, 1919; vol. 20, 1920.

Ostravský kraj, vol. 13, 1918; vol. 14, 1919; vol. 33, 1938.

Polední deník, vol. 39, 1938.

BECK, Petr: Samuel Scharf, židovský hasič z Orlové a český antisemitismus, in: Židé ve Slezsku. Studie k dějinám Židů ve Slezsku, SPYRA, Janusz - WODZIŃSKI, Marcin (eds.), Český Těšín 2001, 104-111.

BORÁK, Mečislav: Situace židovského obyvatelstva na území českého Slezska v době okupace (1938-1945), in: Židé ve Slezsku. Studie k dějinám Židů ve Slezsku, SPYRA, Janusz - WODZIŃSKI, Marcin (eds.), Český Těšín 2001, 142-152.

CÉSAR, Josef - ČERNÝ, Bohumil: Politika německých buržoazních stran v Československu v letech 1918-1938, část II, Praha 1962.

ČERMÁKOVÁ, Radka: Československá pluralistická demokratická společnost ve stínu nacistického Německa, in: Židovská menšina v Československu ve 30. letech, POJAR, Miloš - SOUKUPOVÁ, Blanka - ZAHRADNÍKOVÁ, Marie (eds.), Praha 2004, 9-20.

DRÁBKOVÁ, Světlana: Vztah katolické církve a Židů v období aktivního antisemitismu vyvolaného nacismem, Dissertation thesis, Olomouc 2004. Department of church history of Cyril and Methodius Faculty of Theology of Palacký University in Olomouc.

FRANKL, Michal: "Emancipace od židů". Český antisemitismus na konci 19. století, Praha - Litomyšl 2007.

GAWRECKÁ, Marie: Němci ve Slezsku 1918-1938, Opava 2002.

GAWRECKI, Dan: Politické a národnostní poměry v Těšínském Slezsku 1918-1938, Studie o Těšínsku, vol. 15, Český Těšín 1999. 
GAWRECKI, Dan et al.: Dějiny Českého Slezska 1740-2000, part I, Opava 2003.

GRACOVÁ, Blažena: Židovské obyvatelstvo Ostravska v období druhé republiky, in: Sborník prací Filozofické fakulty Ostravské univerzity - Historie/Historica, 153, 1995, 3, 73-87.

GREGOROVIČ, Miroslav: Kapitoly o českém fašismu. Fašismus jako měřítko politické dezorientace. Legenda a skutečnost, Praha 1995.

HABRMANOVÁ, Magda: Český fašistický tisk na Ostravsku, in: Slezský sborník, 91, 1993, 1/2, 44-53.

HABRMANOVÁ, Magda: Národní obec fašistická, in: Časopis Slezského muzea: série B vědy historické, 42, 1993, 3, 225-236.

JAWORSKI, Wojciech: Żydzi w Cieszynie w okresie międziwojennym, in: Pamiętnik cieszyński, vol. 6, 1993, 96-103.

KLADIWA, Pavel - POKLUDOVÁ, Andrea - KAFKOVÁ, Renata: Lesk a bída obecních samospráv Moravy a Slezska 1850-1914. Muži z radnice, part II., vol. 1, Ostrava 2008.

KOCOUREK, Ludomír: Okupované pohraničí a holocaust, in: Historie okupovaného pohraničí 12, RADVANOVSKÝ, Zdeněk (ed.), Ústí nad Labem 2006, 73-170.

KREJČOVÁ, Helena: Židovská komunita v Sudetech a její osudy po Mnichovu, in: Židé v Sudetech/Die Juden im Sudetenland, OTTE, Anton (ed.), Praha 2000, 129-152.

KRÓL, Jan: Żydzi na Śląsku Cieszyńskim, in: Kalendarz Cieszyński, vol. 6, 1990, 59-68.

KURAL, Václav - RADVANOVSKÝ, Zdeněk: „Sudety” pod hákovým křǐ̌em, Ústí nad Labem 2002.

MíŠKOVÁ, Alena: Od Schönerera ke genocidě?, in: Židé v Sudetech/Die Juden im Sudetenland, OTTE, Anton (ed.), Praha 2000, 47-86.

MÜLLER, Karel et al.: Dějiny českých měst, Opava, Praha 2006.

PASÁK, Tomáš: Český fašismus 1922-1945 a kolaborace 1939-1945, Praha 1999.

PASZ, Franciszek: Żydzi i My w Cieszynie, Cieszyn 1995.

PAVLÍČEK, Jaromír: Český fašismus, in: Politické strany. Vývoj politických stran a hnutí v českých zemích a Československu 1861-2004, Období 1861-1938, part 1, MALÍŘ, Jiří MAREK, Pavel (eds.), Brno 2005, 629-653.

PLAČEK, Vilém: Prajzáci aneb k osudům Hlučínska 1742-1960, Hlučín 2000.

RATAJ, Jan: Český antisemitismus v proměnách let 1918-1945, in: Židé v české a polské občanské společnosti/Żydzi w polskim i czeskim społeczeństwie obywatelskim, VALENTA, Jaroslav - TOMASZEWSKI, Jerzy (eds.), Praha 1999, 45-64.

SOUKUPOVÁ, Blanka: Česká identita po vzniku Československé republiky. Antisemitismus jako faktor upevnění jsoucnosti? 1918-1920, in: Židovská menšina v Československu ve 20. letech, SOUKUPOVÁ, Blanka - ZAHRADNÍKOVÁ, Marie (eds.), Praha 2003, 21-35.

SOUKUPOVÁ, Blanka: Český antisemitismus v podmínkách pluralistické demokratické společnosti národního státu, in: Židovská menšina v Československu ve 30. letech, POJAR, Miloš - SOUKUPOVÁ, Blanka - ZAHRADNÍKOVÁ, Marie (eds.), Praha 2004, 21-35.

SPYRA, Janusz: Židé v rakouském Slezsku (1742-1918). Nástin dějin, in: Židé ve Slezsku. Studie k dějinám Židů ve Slezsku, SPYRA, Janusz - WODZIŃSKI, Marcin (eds.), Český Těšín 2001, 7-47.

SPYRA, Janusz: Po stopách těšínských Židů: malý průvodce po židovských památkách v Cieszyně a Českém Těšíně, Cieszyn 2004.

SPYRA, Janusz: Ztracený svět Židů na Těšínském Sleszku / Utracony świat Żydów na Śląsku Cieszyńskim, Český Těšín 2013 
STEJSKAL, Jan - TESAŘ, Petr - KUČA, Pavel: Otisky poutníka Ahasvera. Z historie židovské obce v oblasti Krnova, Bruntálu, Budišova nad Budišovskou a Osoblažska, Moravský Beroun 2002.

SZYMECZEK, Józef: Židé na Těšínsku, [online], available at: http://www.go-east-mission.net/dateien/cz/146_260209.pdf [cit. 24-11-2014]

ŠEBEK, Jaroslav: Politické strany německé menšiny, in: Politické strany. Vývoj politických stran a hnutí v českých zemích a Československu 1861-2004, Období 1861-1938, part 1, MALÍŘ, Jiř́ - MAREK, Pavel (eds.), Brno 2005, 861-891.

TOMASZEWSKI, Jerzy: Zarys dziejów Żydów w Polsce w latach 1918-1939, Warszawa 1990.

TUREK, Alois: Předmájové dělnické bouře, 1. máj 1890 v Opavě, in: Sborník k 10. výročí osvobození města, Ostrava, 1956.

WANATOWICZ, Maria W.: Historia społeczno-polityczna Górnego Śląska a Śląska Cieszyńskiego w latach 1918-1945, Katowice 1994.

ZIMMERMANN, Volker: Sudetští Němci v nacistickém státě. Politika a nálada obyvatelstva v Řišské župě Sudety (1938-1945), Praha 2001.

ŽÁČEK, Rudolf: Slezsko. Stručná historie států, Praha 2005. 